\title{
Tele-Communications 2.0: The Age of the Internet
}

\author{
Vahagn Jerbashian* \\ University of Barcelona, BEAT, and CERGE-EI \\ Anna Kochanova ${ }^{\dagger}$ \\ Cardiff Business School
}

June 8, 2018

\begin{abstract}
Over the past few decades, the Internet has become the major tool for communication, greatly replacing the traditional telecommunication technologies. We use industry-level evidence from 21 European countries and the period 1997-2007 and identify the changing effects of traditional telecommunication technologies and the Internet on the functioning of markets. Specifically, we show that the effect of the traditional telecommunication technologies on competition in services and goods markets has dissipated and has become insignificant during this period. In contrast, the effect of the Internet has gained a significant momentum.
\end{abstract}

Keywords: Telecommunications; The Internet; Product Market Competition JEL classifications: L16; O25; O33

\footnotetext{
*Address: Av. Diagonal 696, 08034 Barcelona, Spain. E-mail: vahagn.jerbashian@ub.edu. ORCID ID: 0000-0003-4189-2896. CERGE-EI is a joint workplace of Charles University in Prague and the Economics Institute of the Czech Academy of Sciences, Prague, Czech Republic.

†Address: Cardiff Business School, CF103EU Cardiff, UK. E-mail: kochanovaa@cardiff.ac.uk. ORCID ID: 0000-0003-3531-7561.
} 


\section{Introduction}

Telecommunication technologies are almost everywhere nowadays. Their use ranges from ordinary phone calls to emails and browsing, and they have a profound impact on economic performance. These technologies have increased the productivity of businesses and have improved the functioning of the markets by reducing information acquisition costs (e.g., see Röller and Waverman, 2001; Jensen, 2007; Czernich et al., 2011; Jerbashian and Kochanova, 2017). In particular, Jerbashian and Kochanova (2017) show that the wider adoption and more intensive use (diffusion) of telecommunication technologies increases competition in services and goods markets. They conjecture that this result holds because costs of entry and search costs for products decline with information acquisition costs.

In this paper, we identify the changing effects of traditional telecommunication technologies (e.g., telephones and fax) and the Internet on competition in services and goods markets. We use industry-level data from 21 European countries and show that the effect of traditional telecommunications on competition was large and significant in the 90s. However, it faded and became insignificant in the beginning of the 2000s. In contrast, the effect of the Internet was insignificant in the 90s. It has become large and significant starting from the beginning of the 2000s, thus greatly replacing the effect of traditional telecommunication technologies. An appealing explanation for these results is that, with the evolution of telecommunication technologies, the Internet has greatly replaced the traditional telecommunications in terms of the use and the impact on markets.

Our result contributes to the literature on information and communication technologies by providing evidence on the evolution of the economic impact of these technologies, as these technologies undergo improvements. It also contributes to the literature on general purpose technologies. Telecommunication technologies are general purpose technologies since their use is pervasive and they affect the functioning of businesses and markets. Telecommunication technologies seem to be special, however, since there have been substantial improvements in these technologies as compared to other general pur-

pose technologies such as, for example, electricity (Jovanovic and Rousseau, 2005). Our 
result identifies one way how and the date when the latest iteration of telecommunication technologies, the Internet, has replaced its older counterpart, the traditional telecommunications, as a general purpose technology. This result has also a policy implication that, starting from the early 2000s, antitrust policies and policies promoting the diffusion of the Internet can be complementary.

\section{Methodology and Data}

Let Competition ${ }_{c, i, t}$ represent the level of competition in country $c$ and industry $i$, which is averaged over 3 years period with an initial year $t$. Let Diffusion of Telecommunications ${ }_{c, t}$ and Diffusion of the Internet ${ }_{c, t}$ be measures of the diffusion of traditional telecommunication technologies and the Internet in year $t$ and Dependence be a measure of industries' technological dependence on telecommunication technologies. We estimate the following specification for 1997-2007 period:

$$
\begin{aligned}
& \text { Competition }_{c, i, t}=\quad \alpha_{1, c, t}+\alpha_{2, i, t} \\
& +\alpha_{3, t} \cdot\left(\text { Dependence }_{i} \times \text { Diffusion of Telecommunications }_{c, t}\right)
\end{aligned}
$$

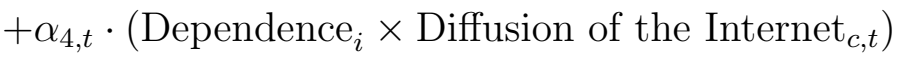

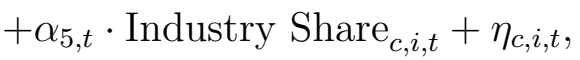

where $\alpha_{1, c, t}$ and $\alpha_{2, i, t}$ are country and industry fixed effects, and $\eta_{c, i, t}$ is the error term. Industry Share s,i,t $_{\text {is }}$ the initial share of an industry in a country in total output, which captures potential convergence effects. Our focus is on the coefficients of the interaction terms, $\alpha_{3, t}$ and $\alpha_{4, t}{ }^{1}$

Regression specification (1) is a modified version of the specification of Jerbashian and Kochanova (2017). It includes both the diffusion of traditional telecommunication technologies and the diffusion of the Internet and allows for time varying coefficients in order to separately identify the evolution of the effects of these technologies. The test in speci-

\footnotetext{
${ }^{1}$ All fixed effects and coefficients are allowed to vary with time in the specification (1). This implies that $\alpha_{3, t}$ and $\alpha_{4, t}$ are identified from within country and industry variation of the interaction terms.
} 
fication (1) has a difference-in-differences form, which has several advantages. It permits country and industry fixed effects, which can be important for capturing, for example, demand characteristics and fixed costs of entry into industries. It does not depend on a particular country-level model of diffusion of traditional telecommunication technologies and the Internet. This alleviates concerns with omitted variables and endogeneity of the diffusion of these technologies. The dependent variable is averaged over 3 year forward rolling window for each sample year, and we use the initial values of telecommunication and internet diffusion measures from the rolling window. This helps us to further alleviate the reverse causality concerns.

We use the data of Jerbashian and Kochanova (2017) throughout the analysis. We also use their main measures of product market competition and industries' dependence on telecommunication technologies. The measure of the level of competition is the price cost margin, which is the empirical analogue of the Lerner index. ${ }^{2}$ In turn, the measure of dependence on telecommunication technologies is the share of expenditures on telecommunications out of total expenditures on intermediate inputs in US industries averaged over the sample period.

Our measure of the diffusion of the Internet is the logarithm of the number of (fixedline) internet subscribers per capita. In turn, we use the number of fixed-lines and mobile telephone subscribers to construct our measure of diffusion of traditional telecommunication technologies. Fixed telephone lines have been extensively used for dial-up internet connection and, currently, they are used for DSL internet connection. To eliminate this variation, we subtract the number of (fixed line) internet subscribers from the fixed-lines and mobile telephone subscribers, compute the ratio of this difference and population, and use the logarithm of this ratio as the measure of diffusion of traditional telecommunications. $^{3}$

\footnotetext{
${ }^{2}$ The original data for price cost margin are till 2007. We extend the sample period till 2009 using data from the OECD STAN database, which is the source of the original data.

${ }^{3}$ Our results are qualitatively the same when we do not subtract the number of internet subscribers and use the number of fixed-lines and mobile telephone subscribers per capita as our measure of the diffusion of traditional telecommunications.
} 
We average the measures of the diffusion of traditional telecommunications and the Internet across countries and illustrate the evolution of averages and their 95 percent confidence intervals in Figure 1. Both diffusion measures have grown over time because of higher uptake of these technologies. The measure of the diffusion of the Internet has a lower value than the measure of the diffusion of traditional telecommunications. However, it grows more rapidly than the latter at least in the beginning of the sample years. This pattern suggests that the Internet was a less mature technology in terms of its uptake and use than the traditional telecommunication technologies in the beginning of sample years. In turn, the confidence intervals of both diffusion measures have shrunk over time, which implies that sample countries have gradually become more similar in terms of the uptake of these technologies. ${ }^{4}$

Figure 1: The Diffusion of Telecommunications and the Diffusion of the Internet

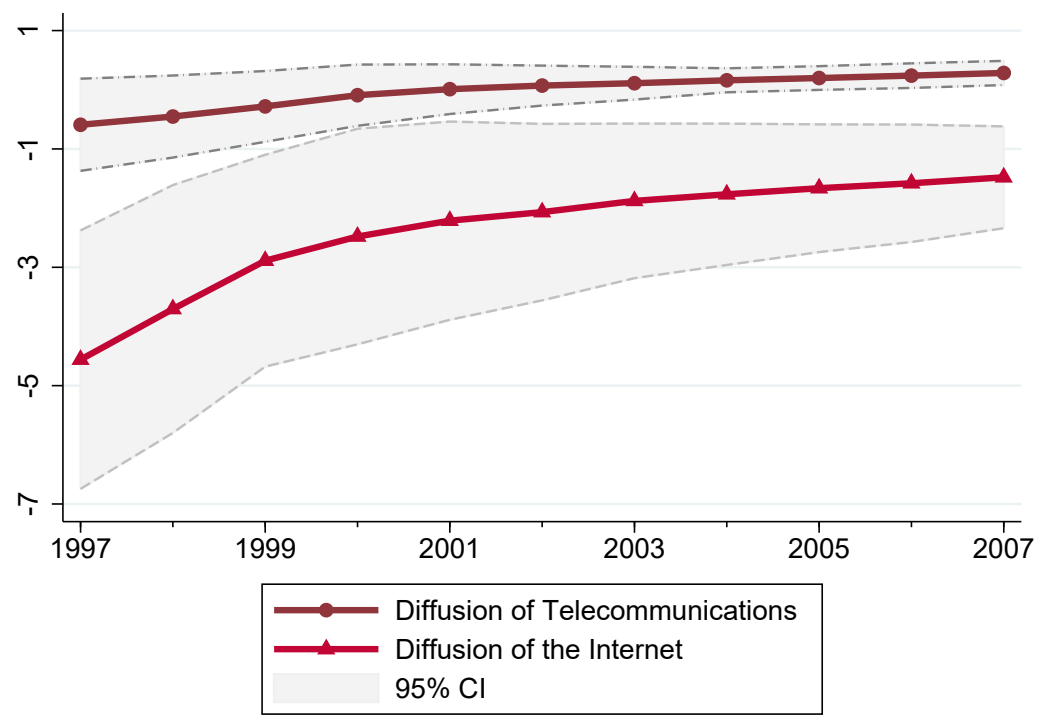

Note: This figure offers the 95 percent confidence intervals and the country-level averages of the Diffusion of Telecommunications (circle tick symbols) and the Diffusion of the Internet (triangle tick symbols).

Price cost margin is an inverse measure of competition. This implies that the more intensive use and wider adoption of traditional telecommunications and the Internet are associated with higher competition in year $t$ if $\alpha_{3, t}$ and $\alpha_{4, t}$ are negative and significant.

\footnotetext{
${ }^{4}$ Table 1 in the Data Appendix offers the summary statistics of all variables.
} 


\section{Results and Discussion}

We start with estimating restricted versions of the specification (1). Panel A of Table 1 reports the estimation results when we drop from the specification (1) the interaction term containing the Diffusion of the Internet. Panel B reports the results when we drop the interaction term containing the Diffusion of Telecommunications. All estimated coefficients on the interaction terms are negative and significant, but the coefficients in Panel A for 2005, 2006, and 2007.

Table 1: The Effects of Traditional Telecommunications and the Internet on Competition

\begin{tabular}{|c|c|c|c|c|c|c|c|c|c|c|c|}
\hline Panel $A$ & 1997 & 1998 & 1999 & 2000 & 2001 & 2002 & 2003 & 2004 & 2005 & 2006 & 2007 \\
\hline $\begin{array}{l}\text { Dependence } \\
\times \text { Diffusion of } \\
\text { Telecommunications }\end{array}$ & $\begin{array}{c}-2.52^{* * *} \\
(0.60)\end{array}$ & $\begin{array}{c}-3.20^{* * *} \\
(0.69)\end{array}$ & $\begin{array}{c}-4.26^{* * *} \\
(0.77)\end{array}$ & $\begin{array}{c}-4.07^{* * *} \\
(0.89)\end{array}$ & $\begin{array}{c}-4.25^{* * *} \\
(1.09)\end{array}$ & $\begin{array}{c}-4.47^{* * *} \\
(1.38)\end{array}$ & $\begin{array}{c}-4.86^{* * *} \\
(1.64)\end{array}$ & $\begin{array}{c}-5.19^{* *} \\
(2.26)\end{array}$ & $\begin{array}{l}-2.48 \\
(2.33)\end{array}$ & $\begin{array}{c}2.36 \\
(1.97)\end{array}$ & $\begin{array}{c}3.06 \\
(1.92)\end{array}$ \\
\hline Industry Share & $\begin{array}{c}0.61^{* *} \\
(0.25)\end{array}$ & $\begin{array}{c}0.63^{* * *} \\
(0.22)\end{array}$ & $\begin{array}{c}0.46^{* *} \\
(0.20)\end{array}$ & $\begin{array}{c}0.48^{* *} \\
(0.24)\end{array}$ & $\begin{array}{c}0.44^{*} \\
(0.25)\end{array}$ & $\begin{array}{l}0.40^{*} \\
(0.24)\end{array}$ & $\begin{array}{c}0.32 \\
(0.21)\end{array}$ & $\begin{array}{c}0.28 \\
(0.21)\end{array}$ & $\begin{array}{c}0.24 \\
(0.22)\end{array}$ & $\begin{array}{c}0.04 \\
(0.21)\end{array}$ & $\begin{array}{c}0.06 \\
(0.23)\end{array}$ \\
\hline Panel $B$ & 1997 & 1998 & 1999 & 2000 & 2001 & 2002 & 2003 & 2004 & 2005 & 2006 & 2007 \\
\hline $\begin{array}{l}\text { Dependence } \\
\times \text { Diffusion of } \\
\text { the Internet }\end{array}$ & $\begin{array}{c}-0.53^{* *} \\
(0.22)\end{array}$ & $\begin{array}{c}-0.86^{* * *} \\
(0.24)\end{array}$ & $\begin{array}{c}-1.12^{* * *} \\
(0.26)\end{array}$ & $\begin{array}{c}-1.08^{* * *} \\
(0.29)\end{array}$ & $\begin{array}{c}-1.17^{* * * *} \\
(0.34)\end{array}$ & $\begin{array}{c}-1.35^{* * *} \\
(0.39)\end{array}$ & $\begin{array}{c}-1.23^{* * *} \\
(0.45)\end{array}$ & $\begin{array}{c}-1.64^{* * *} \\
(0.45)\end{array}$ & $\begin{array}{c}-2.04^{* * *} \\
(0.48)\end{array}$ & $\begin{array}{c}-2.47^{* * *} \\
(0.52)\end{array}$ & $\begin{array}{c}-2.44^{* * *} \\
(0.57)\end{array}$ \\
\hline Industry Share & $\begin{array}{c}0.60^{* *} \\
(0.25)\end{array}$ & $\begin{array}{c}0.64^{* * *} \\
(0.22)\end{array}$ & $\begin{array}{c}0.46^{* *} \\
(0.20)\end{array}$ & $\begin{array}{c}0.50^{* *} \\
(0.24)\end{array}$ & $\begin{array}{l}0.46^{*} \\
(0.25)\end{array}$ & $\begin{array}{l}0.46^{*} \\
(0.24)\end{array}$ & $\begin{array}{l}0.36^{*} \\
(0.21)\end{array}$ & $\begin{array}{c}0.35 \\
(0.21)\end{array}$ & $\begin{array}{c}0.33 \\
(0.23)\end{array}$ & $\begin{array}{c}0.14 \\
(0.22)\end{array}$ & $\begin{array}{c}0.15 \\
(0.24)\end{array}$ \\
\hline Panel $C$ & 1997 & 1998 & 1999 & 2000 & 2001 & 2002 & 2003 & 2004 & 2005 & 2006 & 2007 \\
\hline $\begin{array}{l}\text { Dependence } \\
\times \text { Diffusion of } \\
\text { Telecommunications }\end{array}$ & $\begin{array}{c}-3.07^{* * *} \\
(0.99)\end{array}$ & $\begin{array}{c}-2.30^{* *} \\
(1.14)\end{array}$ & $\begin{array}{c}-3.58^{* *} \\
(1.75)\end{array}$ & $\begin{array}{c}-2.77^{* *} \\
(1.23)\end{array}$ & $\begin{array}{l}-2.29 \\
(1.49)\end{array}$ & $\begin{array}{l}-2.49 \\
(1.80)\end{array}$ & $\begin{array}{l}-3.37 \\
(2.10)\end{array}$ & $\begin{array}{l}-1.90 \\
(3.20)\end{array}$ & $\begin{array}{c}0.42 \\
(2.86)\end{array}$ & $\begin{array}{c}2.76 \\
(2.09)\end{array}$ & $\begin{array}{c}1.32 \\
(2.04)\end{array}$ \\
\hline $\begin{array}{l}\text { Dependence } \\
\times \text { Diffusion of } \\
\text { the Internet }\end{array}$ & $\begin{array}{c}0.22 \\
(0.34)\end{array}$ & $\begin{array}{c}-0.34 \\
(0.38)\end{array}$ & $\begin{array}{l}-0.25 \\
(0.55)\end{array}$ & $\begin{array}{l}-0.55 \\
(0.39)\end{array}$ & $\begin{array}{c}-0.83^{* *} \\
(0.42)\end{array}$ & $\begin{array}{c}-1.11^{* *} \\
(0.44)\end{array}$ & $\begin{array}{c}-1.01^{* *} \\
(0.50)\end{array}$ & $\begin{array}{c}-1.53^{* * *} \\
(0.57)\end{array}$ & $\begin{array}{c}-2.06^{* * *} \\
(0.55)\end{array}$ & $\begin{array}{c}-2.49 * * * \\
(0.53)\end{array}$ & $\begin{array}{c}-2.38 * * * \\
(0.57)\end{array}$ \\
\hline Industry Share & $\begin{array}{c}0.61^{* *} \\
(0.25)\end{array}$ & $\begin{array}{c}0.64^{* * *} \\
(0.22)\end{array}$ & $\begin{array}{c}0.46^{* *} \\
(0.20)\end{array}$ & $\begin{array}{c}0.51^{* *} \\
(0.24)\end{array}$ & $\begin{array}{l}0.47^{*} \\
(0.25)\end{array}$ & $\begin{array}{l}0.46^{*} \\
(0.24)\end{array}$ & $\begin{array}{l}0.37^{*} \\
(0.21)\end{array}$ & $\begin{array}{c}0.35 \\
(0.21)\end{array}$ & $\begin{array}{c}0.32 \\
(0.23)\end{array}$ & $\begin{array}{c}0.13 \\
(0.22)\end{array}$ & $\begin{array}{c}0.15 \\
(0.24)\end{array}$ \\
\hline
\end{tabular}

Note: This table reports the results from estimation of the specification (1), where the dependent variable is the price cost margin. Panel A offers the estimation results for a restricted version of the specification (1) where we drop the Diffusion of the Internet and estimate $\alpha_{3, t}$. In Panel B, we consider a restricted version of the specification (1) where we drop the Diffusion of Telecommunications and estimate $\alpha_{4, t}$. In Panel C, we consider the unrestricted version of the specification (1) and jointly estimate $\alpha_{3, t}$ and $\alpha_{4, t}$. In all panels, the regressions use the least squares estimation method and include full sets of industry-time and country-time fixed effects, which are not reported. Standard errors are clustered at the countryindustry level are in parentheses. ${ }^{* * *}$ indicates significance at the $1 \%$ level, ${ }^{* *}$ at the $5 \%$ level, and ${ }^{*}$ at the $10 \%$ level. The number of observations and the number of clusters in all panels are 9413 and 899. In turn, the adjusted R-squared is 0.642 in Panel A, 0.646 in Panel B, and 0.648 in Panel C.

These results provide suggestive evidence that both the traditional telecommunications and the Internet have had positive effect on competition in services and goods markets in 
sample years. According to Jerbashian and Kochanova (2017), competition has increased with the diffusion of these technologies because they reduce information acquisition costs and, thus, they reduce the costs of entry and search costs for products.

The results in Panels $\mathrm{A}$ and $\mathrm{B}$ are subject to a caveat, however. The traditional telecommunication technologies and the Internet were highly substitutable in the $90 \mathrm{~s}$. In turn, the Internet has greatly replaced the traditional telecommunications more recently as a new and more advanced means of communication. This suggests that the estimated coefficients in Panels A and B are likely to be biased/confounded since, most likely, they also encompass the effect of the omitted interaction term.

Such a concern is absent in Panel $\mathrm{C}$ of Table 1, which reports the point estimates of $\alpha_{3, t}$ and $\alpha_{4, t}$ from the unrestricted version of the specification (1). According to these results, the traditional telecommunication technologies have had significant positive effect on competition in services and goods markets in the end of 90 s and right at the beginning of the 2000s. This effect, however, has dissipated and has become insignificant after 2001. In contrast, the Internet had virtually no impact on competition in services and goods markets in the 90s. However, its effect has gradually gained momentum and has become significant after 2001. An inference from these results is that the Internet has replaced the traditional telecommunications in terms of the use and the impact on markets given that we control for the diffusion of both technologies.

We perform a number of robustness check exercises to ensure that our results are robust. The former transition countries, which joined the European Union in 2004 (Czech Republic, Estonia, Poland, Slovakia, and Slovenia), can be different from the remaining countries in our sample because they have gone through privatization and large structural/industry changes. In turn, the UK can be different from the sample countries because of its development level. We have checked that our results are robust to the exclusion of former transition countries, and the exclusion of the UK. We have also checked that our results are robust to the exclusion of industries, which are the most likely to affect the diffusion of the traditional telecommunications and the Internet and raise reverse causality concerns. We identify these industries as those for which the interaction of their 
share in value added and dependence on telecommunications is above the 10th percentile of the distribution of this interaction across our sample industries, countries, and years. We do not report the results from robustness check exercises for brevity. These results are available upon request.

\section{Conclusions}

In this paper, we provide evidence that the effects of traditional telecommunication technologies and the Internet on competition in services and goods markets have markedly changed over the period 1997-2007. The effect of traditional telecommunication technologies on competition was large and significant in the 90s. It dissipated and became insignificant in the beginning of the 2000s. Meanwhile, the effect of the Internet was insignificant in the $90 \mathrm{~s}$. It has become large and significant starting from the beginning of the 2000s.

A technology is classified as general purpose technology if its use is pervasive and it affects the functioning of businesses and markets. In this regard, our results illustrate an example of how a particular technology, the traditional telecommunications, can gravitate toward loosing its general purpose status and be replaced by its newer version, the Internet. These results also have policy relevance as they suggest that policies motivating a higher diffusion of the Internet can be complementary to antitrust policies starting from the early 2000 s. 


\section{Acknowledgements}

We would like to thank an anonymous referee and Fernando Sanchez-Losada for thoughtful comments. Vahagn Jerbashian gratefully acknowledges the financial support by the Spanish Ministry of Education and Science under Grant ECO2012-34046; the Generalitat of Catalonia under Grant 2014SGR493; and the Grant Agency of the Czech Republic under Project P402/12/G097. All errors remain our own.

\section{References}

Czernich, N., O. Falck, T. Kretschmer, and L. Woessmann (2011). Broadband infrastructure and economic growth. Economic Journal 121(552), 505-532.

Jensen, R. (2007). The digital provide: Information (technology), market performance, and welfare in the South Indian fisheries sectors. Quarterly Journal of Economics 122(3), 879-924.

Jerbashian, V. and A. Kochanova (2017). The impact of telecommunication technologies on competition in services and goods markets: Empirical evidence. Scandinavian Journal of Economics 119(3), 628-655.

Jovanovic, B. and P. L. Rousseau (2005). General purpose technologies. In P. Aghion and S. N. Durlauf (Eds.), Handbook of Economic Growth, Volume 1, pp. 1181-1224. North-Holland: Elsevier B.V.

Röller, L.-H. and L. Waverman (2001). Telecommunications infrastructure and economic development: A simultaneous approach. American Economic Review 91(4), 909-923. 


\section{A Data Appendix}

Table A: Summary Statistics

\begin{tabular}{|c|c|c|c|c|c|}
\hline \multicolumn{6}{|l|}{ Panel A - Country-year-level Variables } \\
\hline Panel A.1 - Sample Period 1997-2007 & Obs & Mean & $\mathrm{SD}$ & Min & Max \\
\hline Diffusion of Telecommunications & 231 & -0.03 & 0.36 & -1.56 & 0.49 \\
\hline Diffusion of the Internet & 231 & -2.39 & 1.21 & -6.99 & -0.81 \\
\hline Panel A.2 - Sample Period 1997-2000 & \multicolumn{2}{|c|}{ Correlation } & \multicolumn{2}{|c|}{$0.83^{* * *}$} & \\
\hline Diffusion of Telecommunications & 84 & -0.35 & 0.38 & -1.56 & 0.18 \\
\hline Diffusion of the Internet & 84 & -3.41 & 1.28 & -6.99 & -0.99 \\
\hline Panel A.3 - Sample Period 2001-2007 & \multicolumn{2}{|c|}{ Correlation } & \multicolumn{2}{|c|}{$0.80^{* * *}$} & \\
\hline Diffusion of Telecommunications & 147 & 0.15 & 0.16 & -0.64 & 0.49 \\
\hline \multirow[t]{2}{*}{ Diffusion of the Internet } & 147 & -1.81 & 0.67 & -3.98 & -0.81 \\
\hline & \multicolumn{2}{|c|}{ Correlation } & \multicolumn{2}{|c|}{$0.49^{* * *}$} & \\
\hline Panel B - Industry-country-year-level Variables & Obs & Mean & $\mathrm{SD}$ & Min & $\operatorname{Max}$ \\
\hline Price Cost Margin & 9413 & 0.18 & 0.12 & 0.02 & 0.71 \\
\hline Industry Share & 9413 & 0.02 & 0.03 & 0.00 & 0.32 \\
\hline Panel C - Industry-level Variables & Obs & Mean & $\mathrm{SD}$ & Min & $\operatorname{Max}$ \\
\hline Dependence & 47 & 0.01 & 0.01 & 0.00 & 0.05 \\
\hline
\end{tabular}

Note: This table reports basic statistics for the variables. In addition to the basic statistics, Panel A offers the correlation between the Diffusion of Telecommunications and the Diffusion of the Internet for the entire sample period and for the periods 1997-2000 and 2001-2007. ${ }^{* * *}$ indicates significance at the $1 \%$ level.

Table B: Definitions and Sources of Variables

\begin{tabular}{|c|c|}
\hline Variable Name & Definition and Source \\
\hline Competition & $\begin{array}{l}\text { Price cost margin averaged over } 3 \text { year forward rolling window for each sample year. } \\
\text { Price cost margin is the empirical analogue of the Lerner index. It is defined as the ratio } \\
\text { of the difference between output and labor and intermediate costs, on the one hand, and } \\
\text { output, on the other [i.e., (Output - Labor and Intermediate Input Costs)/Output]. }\end{array}$ \\
\hline Dependence & $\begin{array}{l}\text { The share of expenditures on telecommunications out of total expenditures on interme- } \\
\text { diate inputs in US industries averaged over the sample period. }\end{array}$ \\
\hline $\begin{array}{l}\text { Diffusion of Telecommuni- } \\
\text { cations }\end{array}$ & $\begin{array}{l}\text { The logarithm of the number of fixed-line and mobile telephone subscribers minus the } \\
\text { number of (fixed line) internet subscribers per capita. }\end{array}$ \\
\hline Diffusion of the Internet & The logarithm of the number of (fixed line) internet subscribers per capita. \\
\hline
\end{tabular}


Table B - (Continued)

Variable Name Definition and Source

Industry Share

The ratio of output in an industry in a country to the total (business) output in the country.

Sample countries are Austria, Belgium, Czech Republic, Denmark, Estonia, Finland, France, Germany, Greece, Hungary, Ireland, Italy, Netherlands, Norway, Poland, Portugal, Slovakia, Slovenia, Spain, Sweden, and the UK; sample industries (ISIC rev. 3.1) are 10, 11, 13-36, 40, 41, 45, 50-52, 55, 60-63, 65-67, 70-74, 92, and 93; and sample period is 1997-2009.

Data Sources: Jerbashian and Kochanova (2017) and BEA, ITU, and OECD STAN. 